\title{
Effect of Phosphorus Rates and Varieties on Grain Yield, Nutrient Uptake and Phosphorus Efficiency of Tef [Eragrostis tef (Zucc.) Trotter]
}

\author{
Alemayehu Balcha \\ Department of Plant Science, College of Agriculture, Wolaita Sodo University, Wolaita Sodo, Ethiopia. \\ Email: albalcha@yahoo.com
}

Received November $19^{\text {th }}, 2013$; revised December $26^{\text {th }}, 2013$; accepted January $13^{\text {th }}, 2014$

Copyright (C) 2014 Alemayehu Balcha. This is an open access article distributed under the Creative Commons Attribution License, which permits unrestricted use, distribution, and reproduction in any medium, provided the original work is properly cited. In accordance of the Creative Commons Attribution License all Copyrights (c) 2014 are reserved for SCIRP and the owner of the intellectual property Alemayehu Balcha. All Copyright (C) 2014 are guarded by law and by SCIRP as a guardian.

\section{ABSTRACT}

Tef [Eragrostis tef (Zucc.) Trotter] is the major cereal crop in Ethiopia. Increasing tef yield requires improving soil phosphorus (P) supply and identifying $P$ efficient varieties. An experiment was conducted at Wenago, Ethiopia, from May to August, 2011, during the main cropping season, to investigate the role of $P$ supply in relation to grain yield, nutrient uptake (N, P, Ca and $\mathrm{K}$ ) and $\mathrm{P}$ efficiency, and to investigate varietal differences for these parameters using four $P$ rates $\left(0,3,6\right.$ and $\left.9 \mathrm{~g} / \mathrm{m}^{2} \mathrm{P}_{2} \mathrm{O}_{5}\right)$ as main plots and three tef varieties (DZ-Cr-37, DZ-Cr-82, and DZ-Cr-255) as subplots in split-plot design with three replications. For respective 0, 3, 6 and $9 \mathrm{~g} / \mathrm{m}^{2} \mathrm{P}_{2} \mathrm{O}_{5}$, grain yield was 84, 203, 215 and $218 \mathrm{~g} / \mathrm{m}^{2}$, total biomass $586,897,971$ and $1016 \mathrm{~g} / \mathrm{m}^{2}$, and harvest index $0.14,0.23$, 0.22 and 0.22. For respective variety DZ-Cr-37, DZ-Cr-82, and DZ-Cr-255, grain yield was 194, 182 and 163 $\mathrm{g} / \mathrm{m}^{2}$, total biomass 810,922 and $871 \mathrm{~g} / \mathrm{m}^{2}$, and harvest index $0.24,0.19$ and 0.18 . Total plant nutrients $\left(\mathrm{g} / \mathrm{m}^{2}\right)$ for respective $0,3,6$ and $9 \mathrm{~g} / \mathrm{m}^{2} \mathrm{P}_{2} \mathrm{O}_{5}$ were $\mathrm{N} 3.92,7.95,9.49$ and 10.80, $\mathrm{P} 0.57,1.20,1.49$ and 1.66, calcium $0.16,0.27$, 0.38 and 0.45 , and $K 4.45,7.96,9.70$ and 10.50. For respective 3,6 and $9 \mathrm{~g} / \mathrm{m}^{2} \mathrm{P}_{2} \mathrm{O}_{5}$, P physiological efficiency (PE) was 224, 153 and 127, apparent recovery (AR) $0.49,0.36$ and 0.28 , and agronomic efficiency (AE) 92,50 and 35. For respective variety DZ-Cr-37, DZ-Cr-82 and DZ-Cr-255, PE was 248, 130 and 126, AR 0.28, 0.44 and 0.41, and AE 68, 57 and 51. The present experiment suggests that excess $P$ supply beyond $3 \mathrm{~g} / \mathrm{m}^{2}$ could result in low grain yield increase and low $P$ recovery requiring soil $P$ assessment prior to fertilizer application. Moreover, variety DZ-Cr-37 may be incorporated in the future breeding programs for $\mathbf{P}$ efficiency in tef.

\section{KEYWORDS}

Tef; Eragrostis Tef; Phosphorus; Grain Yield; Nutrient Uptake; P Efficiency

\section{Introduction}

Tef [Eragrostis tef (Zucc.) Trotter] is the major cereal crop in Ethiopia growing widely from sea level up to $2800 \mathrm{~m}$ above sea level under various rainfall, temperature and soil conditions [1]. However, the average yield of tef is low (less than $1 \mathrm{t} / \mathrm{ha}$ ) [2] which is partly attributed to low soil fertility [3]. In Ethiopia, $\mathrm{N}$ is deficient in almost all soils [4] and P is deficient in about $70 \%$ of soils [5]. $P$ is less available for plant uptake in most tropical soils mainly because of its fixation with Ca in alkaline soils and $\mathrm{Fe}$ and $\mathrm{Al}$ oxides in acidic soils. Moreover, the majority of applied P fertilizers in these soils are fixed and made unavailable for plant uptake [6,7].

The development of $\mathrm{P}$ efficient genotypes with a great ability to grow and yield in soils with limited phosphorus supply improves the sustainability of crop production $[8,9]$. This also reduces production costs associated with $\mathrm{P}$ fertilizer applications and minimizes environmental pollution resulting from run-off and leaching of excess $P$ fertilizer [10]. Phosphorus efficiency of the genotype can be due to its ability to acquire $\mathrm{P}$ from limited soil $\mathrm{P}$ supply and/or its ability to produce high yield per unit $\mathrm{P}$ acquired [11].

The differences in $\mathrm{P}$ uptake involve the differences in 
changing rhizosphere $\mathrm{pH}$, release of organic compounds, and root surface area $[12,13]$ as well as production and secretion of phosphatase to the rhizosphere $[14,15]$. On the other hand, the differences in the use of internal phosphorus may be related to the ability of plants to translocate and use it in dry matter production [16]. Even though, genotypic variation in P efficiency has been reported in several crops such as wheat $[9,17,18]$, maize [19] and rice [20], the information in tef is scanty. This experiment was therefore carried out to investigate the role of $\mathrm{P}$ supply in relation to grain yield, nutrient uptake ( $\mathrm{N}, \mathrm{P}, \mathrm{Ca}$ and $\mathrm{K}$ ) and $\mathrm{P}$ efficiency, and to investigate varietal differences for these parameters in tef.

\section{Materials and Methods}

A field experiment was conducted at Wenago, Ethiopia, during 2011 main cropping season using three commonly grown tef varieties: DZ-Cr-37, DZ-Cr-82, and DZ-Cr255, obtained from Debre-Ziet Agricultural Research Center, Ethiopia. Wenago, $6^{\circ} 19^{\prime} \mathrm{N} 38^{\circ} 16^{\prime} \mathrm{E}$, is located at an altitude of $1763 \mathrm{~m}$ above sea level. It has the average annual rainfall and temperature of $1344 \mathrm{~mm}$ and $20.60^{\circ} \mathrm{C}$, respectively, and for the experiment duration of May to August, the monthly average rainfall was $166 \mathrm{~mm}$, and the average maximum and minimum temperature was $26.10^{\circ} \mathrm{C}$ and $15.04^{\circ} \mathrm{C}$, respectively. The analysis of soil samples at $0-30 \mathrm{~cm}$ depth for the experimental field was found to be clay texture (51\% clay, sand $29 \%$, and silt $20 \%$ ), pH 5.35 (in $\mathrm{H}_{2} \mathrm{O}$ ), organic matter $2.02 \%$, total $\mathrm{N}$ $0.10 \%$, available P $4.60 \mathrm{ppm}$ (Olsen), exchangeable $\mathrm{Ca}$ and $\mathrm{Mg} 10 \mathrm{meq} / 100 \mathrm{~g}$ each, exchangeable K 23 meq/100g, and CEC $30.40 \mathrm{meq} / 100 \mathrm{~g}$.

The experimental design was a split plot with three replications. The $\mathrm{P}$ rates $\left(0,3,6\right.$ and $\left.9 \mathrm{~g} / \mathrm{m}^{2} \mathrm{P}_{2} \mathrm{O}_{5}\right)$ constituted the main plots and three tef varieties were subplots. Tef varieties were planted at recommended rate of $30 \mathrm{~kg} / \mathrm{ha}$ on 26 May 2011. Each plot consisted of five rows, $1 \mathrm{~m}$ long with spacing of $20 \mathrm{~cm}$ between rows. The distance between replications was $1.5 \mathrm{~m}$ and that of main plots was $2 \mathrm{~m}$. The $40 \mathrm{~kg} / \mathrm{ha} \mathrm{N}$ in the form of urea and diammonium phosphate (DAP) and all $\mathrm{P}$ rates, in the form of DAP, were applied at planting. Each plot was kept free from weeds with frequent hand weeding.

Days to $50 \%$ flowering and maturity, grain yield $\left(\mathrm{g} / \mathrm{m}^{2}\right)$, total biomass $\left(\mathrm{g} / \mathrm{m}^{2}\right)$, harvest index (the ratio of grain yield to total biomass), and plant height $(\mathrm{cm})$, panicle weight (g/plant) and seed weight (g/plant) (averages for five random plants per plot) were recorded. Samples of grain and straw were oven dried at $65^{\circ} \mathrm{C}$ to constant weight before estimating grain yield and total biomass. Grain and straw N were analyzed using Kjeldahl method
[21], and P, Ca and $\mathrm{K}$ were analyzed using methods of Association of Official Analytical Chemists [22]. The nutrient concentration data were used to calculate nutrient uptake in grain and in total plant.

\section{Determination of Phosphorus Efficiency}

Phosphorus efficiency parameters were calculated according to Mengel and Kirbky [6] as:

Physiological efficiency $(\mathrm{PE})=($ GYf-GYc $) /($ TPf-TPc $)$

Apparent recovery $(\mathrm{AR})=(\mathrm{TPf}-\mathrm{TPc}) / \mathrm{Ps}$

Agronomic efficiency $($ AE $)=($ GYf-GYc $) /$ Ps

where GYf = grain yield of fertilized plot, GYc = grain yield of control plot, TPf = total plant $\mathrm{P}$ of fertilized plot, TPc $=$ total plant $\mathrm{P}$ of control plot, and Ps $=$ fertilizer $\mathrm{P}$ supply.

The grain yield and yield related parameters as well as nutrient uptake and P efficiency data were analyzed using GLM procedure of the SAS [23].

\section{Results}

\subsection{Grain Yield and Yield Related Parameters}

Analysis of variance showed that grain yield and yield related parameters except grain filling period were significantly affected by P application. However, the effect of variety was only significant for grain yield, total biomass and harvest index, and that of $\mathrm{P} \times$ variety interaction was only significant for total biomass and harvest index (Table 1).

Grain yield and yield related parameters increased with increasing $\mathrm{P}$ rate except for days to flowering and maturity, and grain filling period. Grain yield increased from 84 to 218, total biomass 586 to 1016, harvest 0.14 to 0.22 , panicle weight 0.49 to 0.73 , and seed weight 0.25 to 0.38 when $P$ rate was increased from 0 to $9 \mathrm{~g} / \mathrm{m}^{2}$ $\mathrm{P}_{2} \mathrm{O}_{5}$. On the other hand, the differences between 3, 6, and $9 \mathrm{~g} / \mathrm{m}^{2} \mathrm{P}_{2} \mathrm{O}_{5}$ rates were not significant for these parameters. In addition, increasing $P$ rate from 0 to $9 \mathrm{~g} / \mathrm{m}^{2}$ $\mathrm{P}_{2} \mathrm{O}_{5}$ reduced days to flowering and maturity by 14 and 13 days, respectively. Varieties DZ-Cr-37, DZ-Cr-82 and DZ-Cr-255 had the grain yield of 194, 182 and 163, respectively. Variety DZ-Cr-37 had also significantly highest value of harvest index compared to varieties DZCr-82 and DZ-Cr-255 (Table 2).

\subsection{Nutrient Uptake}

Grain and total plant nitrogen $(\mathrm{N})$, phosphorus (P), calcium (Ca) and potassium (K) were significantly affected by $\mathrm{P}$ application. The effect of variety was significant for these parameters except total plant $\mathrm{N}$ and that of $\mathrm{P} \times$ variety interaction was only significant for grain $\mathrm{Ca}$ (Table 3). 
Table 1. Significance of mean squares for grain yield and yield related parameters across four phosphorus (P) rates and three tef varieties.

\begin{tabular}{ccccccccccc}
\hline $\begin{array}{c}\text { Source of } \\
\text { variation }\end{array}$ & d.f. & $\begin{array}{c}\mathrm{GY} \\
\left(\mathrm{g} / \mathrm{m}^{2}\right)\end{array}$ & $\begin{array}{c}\mathrm{TB} \\
\left(\mathrm{g} / \mathrm{m}^{2}\right)\end{array}$ & $\mathrm{HI}^{1}(\mathrm{ratio})$ & $\begin{array}{c}\text { PHT } \\
(\mathrm{cm})\end{array}$ & DTF & DTM & GFP & $\begin{array}{c}\text { PW } \\
(\mathrm{g} / \mathrm{plant})\end{array}$ & $\begin{array}{c}\text { SW } \\
(\mathrm{g} / \mathrm{plant})\end{array}$ \\
\hline Replication & 2 & $416 \mathrm{~ns}$ & $3118 \mathrm{~ns}$ & $1.16 \mathrm{~ns}$ & $86 \mathrm{~ns}$ & $10.10 \mathrm{~ns}$ & $17.44 \mathrm{~ns}$ & $1.86 \mathrm{~ns}$ & $0.019 \mathrm{~ns}$ & $4.60 \mathrm{~ns}$ \\
P & 3 & $36734^{* *}$ & $339315^{* *}$ & $144.62^{*}$ & $515^{* *}$ & $326^{* *}$ & $310^{* *}$ & $11.21 \mathrm{~ns}$ & $0.114^{* *}$ & $34.92^{*}$ \\
Error (a) & 6 & 696 & 19968 & 29.95 & 45 & 19.05 & 8 & 4.38 & 0.008 & 5.30 \\
Variety & 2 & $2941^{* *}$ & $38030^{* *}$ & $93.20^{* *}$ & $109 \mathrm{~ns}$ & $2.33 \mathrm{~ns}$ & $3.86 \mathrm{~ns}$ & $3.36 \mathrm{~ns}$ & $0.026 \mathrm{~ns}$ & $3.03 \mathrm{~ns}$ \\
P × Variety & 6 & $267 \mathrm{~ns}$ & $14817^{*}$ & $21.46^{*}$ & $10 \mathrm{~ns}$ & $9.63 \mathrm{~ns}$ & $9.75 \mathrm{~ns}$ & $11.21 \mathrm{~ns}$ & $0.004 \mathrm{~ns}$ & $5.15 \mathrm{~ns}$ \\
Error (b) & 16 & 436 & 5033 & 6.99 & 49 & 14.93 & 41.24 & 4.33 & 0.010 & 5.80 \\
CV(a), \% & & 14.66 & 16.30 & 27.36 & 7.99 & 8.91 & 4.16 & 11.01 & 13.87 & 21.41 \\
CV(b), \% & & 11.60 & 8.18 & 13.22 & 8.33 & 7.89 & 9.44 & 10.95 & 15.41 & 22.40 \\
\hline
\end{tabular}

${ }^{1}$ harvest index was multiplied by $10^{-4} ;{ }^{2}$ seed weight was multiplied by $10^{-3}$; GY = grain yield; TB = total biomass; PHT = plant height; DTF = days to flowering; $\mathrm{DTM}=$ days to maturity; GFP = grain filling period; $\mathrm{PW}=$ panicle weight; $\mathrm{SW}=$ seed weight; ${ }^{*}=$ significant at $\mathrm{p}<0.05 ;{ }^{* *}=$ significant at $\mathrm{p}<0.01$; ns = not significant.

Table 2. Mean values of grain yield and yield related parameters at four phosphorus $(\mathrm{P})$ rates and three tef varieties.

\begin{tabular}{|c|c|c|c|c|c|c|c|c|c|}
\hline $\mathrm{P}$ rate $\left(\mathrm{g} / \mathrm{m}^{2} \mathrm{P}_{2} \mathrm{O}_{5}\right)$ & $\begin{array}{c}\mathrm{GY} \\
\left(\mathrm{g} / \mathrm{m}^{2}\right)\end{array}$ & $\begin{array}{c}\mathrm{TB} \\
\left(\mathrm{g} / \mathrm{m}^{2}\right)\end{array}$ & HI (ratio) & $\begin{array}{l}\text { PHT } \\
(\mathrm{cm})\end{array}$ & DTF & DTM & GFP & $\begin{array}{c}\text { PW } \\
\text { (g/plant) }\end{array}$ & $\begin{array}{c}\text { SW } \\
\text { (g/plant) }\end{array}$ \\
\hline 0 & 84 & 586 & 0.14 & 73 & 58 & 76 & 18 & 0.49 & 0.25 \\
\hline 3 & 203 & 897 & 0.23 & 86 & 49 & 69 & 20 & 0.68 & 0.36 \\
\hline 6 & 213 & 971 & 0.22 & 89 & 46 & 64 & 18 & 0.72 & 0.36 \\
\hline 9 & 218 & 1016 & 0.22 & 90 & 44 & 63 & 19 & 0.73 & 0.38 \\
\hline $\mathrm{LSD}_{0.05}$ & 30 & 163 & 0.063 & 8 & 5 & 3 & ns & 0.10 & 0.08 \\
\hline \multicolumn{10}{|l|}{ Variety } \\
\hline DZ-Cr-37 & 194 & 810 & 0.24 & 81 & 49 & 68 & 19 & 0.69 & 0.33 \\
\hline DZ-Cr-82 & 182 & 922 & 0.19 & 87 & 50 & 69 & 19 & 0.60 & 0.33 \\
\hline DZ-Cr-255 & 163 & 871 & 0.18 & 85 & 50 & 68 & 18 & 0.67 & 0.36 \\
\hline Mean & 180 & 867 & 0.20 & 84 & 49 & 68 & 19 & 0.65 & 0.34 \\
\hline $\mathrm{LSD}_{0.05}$ & 18 & 61 & 0.023 & ns & ns & ns & ns & ns & ns \\
\hline
\end{tabular}

$\overline{\mathrm{GY}}=$ grain yield; $\mathrm{TB}=$ total biomass; $\mathrm{HI}=$ harvest index; $\mathrm{PHT}=$ plant height; $\mathrm{DTF}=$ days to flowering; DTM = days to maturity; GFP = grain filling period; $\mathrm{PW}=$ panicle weight; $\mathrm{SW}=$ seed weight.

Table 3. Significance of mean squares for grain and total plant N, P, Ca and K across four phosphorus (P) rates and three tef varieties.

\begin{tabular}{cccccccccc}
\hline $\begin{array}{c}\text { Source of } \\
\text { variation }\end{array}$ & d.f & $\begin{array}{c}\mathrm{GN} \\
\left(\mathrm{g} / \mathrm{m}^{2}\right)\end{array}$ & $\begin{array}{c}\mathrm{TN} \\
\left(\mathrm{g} / \mathrm{m}^{2}\right)\end{array}$ & $\begin{array}{c}\mathrm{GP} \\
\left(\mathrm{g} / \mathrm{m}^{2}\right)\end{array}$ & $\begin{array}{c}\mathrm{TP} \\
\left(\mathrm{g} / \mathrm{m}^{2}\right)\end{array}$ & $\begin{array}{c}\mathrm{GCa} \\
\left(\mathrm{g} / \mathrm{m}^{2}\right)\end{array}$ & $\begin{array}{c}\mathrm{TCa} \\
\left(\mathrm{g} / \mathrm{m}^{2}\right)^{1}\end{array}$ & $\begin{array}{c}\mathrm{GK} \\
\left(\mathrm{g} / \mathrm{m}^{2}\right)\end{array}$ & $\begin{array}{c}\mathrm{TK} \\
\left(\mathrm{g} / \mathrm{m}^{2}\right)\end{array}$ \\
\hline Replication & 2 & $0.34 \mathrm{~ns}$ & $4.14 \mathrm{~ns}$ & $0.018 \mathrm{~ns}$ & $0.038 \mathrm{~ns}$ & $0.89 \mathrm{~ns}$ & $0.027 \mathrm{~ns}$ & $0.028 \mathrm{~ns}$ & $12.08 \mathrm{~ns}$ \\
$\mathrm{P}$ & 3 & $11.70^{* *}$ & $80.20^{* *}$ & $0.523^{* *}$ & $2.065^{* *}$ & $31.68^{* *}$ & $0.145^{* *}$ & $0.731^{* *}$ & $65.15^{* *}$ \\
Error (a) & 6 & 0.19 & 1.40 & 0.012 & 0.023 & 1.47 & 0.012 & 0.008 & 3.39 \\
Variety & 2 & $1.11^{* *}$ & $1.24 \mathrm{~ns}$ & $0.060^{* *}$ & $0.134^{* *}$ & $28.10^{* *}$ & $0.262^{* *}$ & $0.085^{*}$ & $16.42^{* *}$ \\
P × Variety & 6 & $0.11 \mathrm{~ns}$ & $0.96 \mathrm{~ns}$ & $0.008 \mathrm{~ns}$ & $0.025 \mathrm{~ns}$ & $2.43^{* *}$ & $0.005 \mathrm{~ns}$ & $0.019 \mathrm{~ns}$ & $1.36 \mathrm{~ns}$ \\
Error (b) & 16 & 0.12 & 1.09 & 0.008 & 0.021 & 0.58 & 0.009 & 0.018 & 1.51 \\
CV(a), \% & & 14.92 & 14.72 & 18.72 & 12.38 & 31.02 & 34.62 & 12.88 & 22.58 \\
CV(b), \% & & 11.86 & 12.98 & 15.28 & 11.87 & 19.43 & 29.98 & 19.31 & 15.07 \\
\hline
\end{tabular}

${ }^{1}$ Grain Ca was multiplied by $10^{-4}$; GN = grain N; TN = total plant N; GP = grain P; TP = total plant P; TCa = total plant Ca; GK = grain K; TK = Total plant K;

${ }^{*}=$ significant at $\mathrm{p}<0.05 ;{ }^{* *}=$ significant at $\mathrm{p}<0.01$; ns $=$ not significant. 
Increasing $\mathrm{P}$ rate increased grain and total plant $\mathrm{N}, \mathrm{P}$, Ca and K. Total plant $\mathrm{N}$ increased from 3.92 to $10.80, \mathrm{P}$ 0.57 to 1.66 , Ca 0.16 to 0.45 , and $\mathrm{K} 4.45$ to 10.50 when $\mathrm{P}$ rate was increased from 0 to $9 \mathrm{~g} / \mathrm{m}^{2} \mathrm{P}_{2} \mathrm{O}_{5}$. However, the maximum increase in total nutrient uptake was occurred between 0 and $3 \mathrm{~g} / \mathrm{m}^{2} \mathrm{P}_{2} \mathrm{O}_{5}$ and it was low between 6 and $9 \mathrm{~g} / \mathrm{m}^{2} \mathrm{P}_{2} \mathrm{O}_{5}$. Total plant P for varieties DZ-Cr-37, DZCr-82 and DZ-Cr-255 was 1.11, 1.26 and 1.31, respectively. There were also considerable variations among varieties for grain $\mathrm{N}, \mathrm{P}, \mathrm{Ca}$ and $\mathrm{K}$, and total plant $\mathrm{Ca}$ and K (Table 4).

\subsection{Phosphorus Efficiency}

Physiological efficiency (PE), apparent recovery (AR), and agronomic efficiency (AE) were significantly affected by $\mathrm{P}$ application and variety. However, the effect of $\mathrm{P} \times$ variety interaction was only significant for $\mathrm{PE}$. With increasing $\mathrm{P}$ rate from 3 to $9 \mathrm{~g} / \mathrm{m}^{2} \mathrm{P}_{2} \mathrm{O}_{5}$, $\mathrm{PE}$ deceased from 224 to 127, AR 0.49 to 0.28 , and AE 92 to 35. The respective PE, AR, and AE were 248, 0.28 and 68 for variety DZ-Cr-37; 130, 0.44 and 57 for variety DZ-Cr-82; and 126, 0.41 and 51 for variety DZ-Cr-255 (Table 5).

Table 4. Mean values of grain and total plant N, P, Ca and $\mathrm{K}$ for four phosphorus (P) rates and three tef varieties.

\begin{tabular}{|c|c|c|c|c|c|c|c|c|}
\hline $\begin{array}{c}\text { P rate } \\
\left(\mathrm{g} / \mathrm{m}^{2} \mathrm{P}_{2} \mathrm{O}_{5}\right)\end{array}$ & $\begin{array}{c}\text { GN } \\
\left(\mathrm{g} / \mathrm{m}^{2}\right)\end{array}$ & $\begin{array}{c}\mathrm{TN} \\
\left(\mathrm{g} / \mathrm{m}^{2}\right)\end{array}$ & $\begin{array}{c}\text { GP } \\
\left(\mathrm{g} / \mathrm{m}^{2}\right)\end{array}$ & $\begin{array}{c}\mathrm{TP} \\
\left(\mathrm{g} / \mathrm{m}^{2}\right)\end{array}$ & $\begin{array}{c}\text { GCa } \\
\left(\mathrm{g} / \mathrm{m}^{2}\right)\end{array}$ & $\begin{array}{c}\mathrm{TCa} \\
\left(\mathrm{g} / \mathrm{m}^{2}\right)\end{array}$ & $\begin{array}{c}\mathrm{GK} \\
\left(\mathrm{g} / \mathrm{m}^{2}\right)\end{array}$ & $\begin{array}{c}\mathrm{TK} \\
\left(\mathrm{g} / \mathrm{m}^{2}\right)\end{array}$ \\
\hline 0 & 1.25 & 3.92 & 0.23 & 0.57 & 0.013 & 0.16 & 0.28 & 4.45 \\
\hline 3 & 3.18 & 7.95 & 0.63 & 1.20 & 0.040 & 0.27 & 0.74 & 7.96 \\
\hline 6 & 3.54 & 9.49 & 0.73 & 1.49 & 0.048 & 0.38 & 0.84 & 9.70 \\
\hline 9 & 3.72 & 10.80 & 0.75 & 1.66 & 0.056 & 0.45 & 0.92 & 10.50 \\
\hline $\mathrm{LSD}_{0.05}$ & 0.50 & 1.37 & 0.13 & 0.18 & 0.014 & 0.13 & 0.10 & 2.12 \\
\hline \multicolumn{9}{|l|}{ Variety } \\
\hline DZ-Cr-37 & 3.18 & 7.67 & 0.60 & 1.11 & 0.042 & 0.47 & 0.61 & 7.82 \\
\hline DZ-Cr-82 & 3.00 & 8.17 & 0.65 & 1.26 & 0.053 & 0.29 & 0.70 & 9.45 \\
\hline DZ-Cr-255 & 2.59 & 8.28 & 0.51 & 1.31 & 0.022 & 0.18 & 0.78 & 7.19 \\
\hline Mean & 2.92 & 8.04 & 0.59 & 1.23 & 0.039 & 0.32 & 0.69 & 8.15 \\
\hline $\mathrm{LSD}_{0.05}$ & 0.30 & ns & 0.09 & 0.13 & 0.008 & 0.095 & 0.12 & 1.06 \\
\hline
\end{tabular}

$\mathrm{GN}=$ grain $\mathrm{N}$; TN = total plant N; GP = grain P; TP = total plant P; GCa = grain calcium; $\mathrm{TCa}=$ total plant Ca; $\mathrm{GK}=$ grain $\mathrm{K}$; $\mathrm{TK}=$ Total plant $\mathrm{K}$.

Table 5. Significance of F-ratios, and mean values of physiological efficiency (PE), apparent recovery (AR), and agronomic efficiency (AE) for three phosphorus $(P)$ rates and three tef varieties.

\begin{tabular}{|c|c|c|c|}
\hline$P$ rate $\left(g / \mathrm{m}^{2} \mathrm{P}_{2} \mathrm{O}_{5}\right)$ & $\mathrm{PE}$ & AR & $\mathrm{AE}$ \\
\hline 3 & 224 & 0.49 & 92 \\
\hline 6 & 153 & 0.36 & 50 \\
\hline $\mathrm{LSD}_{0.05}$ & 39 & 0.13 & 11 \\
\hline \multicolumn{4}{|l|}{ Variety } \\
\hline DZ-Cr-82 & 130 & 0.44 & 57 \\
\hline DZ-Cr-255 & 126 & 0.41 & 51 \\
\hline Mean & 168 & 0.38 & 59 \\
\hline $\mathrm{LSD}_{0.05}$ & 37 & 0.09 & 11 \\
\hline \multicolumn{4}{|l|}{ F-ratio $^{1}$} \\
\hline Replication (2) & $0.22 \mathrm{~ns}$ & $1.09 \mathrm{~ns}$ & $1.24 \mathrm{~ns}$ \\
\hline $\mathrm{P}(2)$ & $25.19^{* *}$ & $9.72^{*}$ & $118.19^{* *}$ \\
\hline Error (a) (4) & 884 & 0.01 & 68 \\
\hline Variety (2) & $33.77^{* *}$ & $9.14^{* *}$ & $5.98^{*}$ \\
\hline $\mathrm{P} \times$ Variety & $4.37^{*}$ & $0.79 \mathrm{~ns}$ & $1.63 \mathrm{~ns}$ \\
\hline Error (b) (12) & 1286 & 0.007 & 111 \\
\hline CV(a), \% & 17.70 & 26.32 & 13.98 \\
\hline CV(b), \% & 21.35 & 22.02 & 17.86 \\
\hline
\end{tabular}

${ }^{1}$ numbers in the parentheses are degree of freedom; ${ }^{*}=$ significant at $\mathrm{p}<0.05 ;^{* *}=$ significant at $\mathrm{p}<0.01$; ns $=$ not significant. 


\section{Discussion}

As to the present experiment, the increase in $\mathrm{P}$ rate increased grain yield in tef [24] and soybean [25]; grain yield and total biomass in maize [19], wheat [26], amaranth [27] and sorghum [28]; total biomass in rice [20,29]; and plant height in soybean [25], sorghum [28] and tef [30], because P is involved in several energy transformation and biochemical reactions for plant growth and development. Such an increase in tef performance observed in present experiment with P supply would also indicate the deficiency of $\mathrm{P}$ in this particular soil. On the other hand, low and non-significant increase in yield of tef beyond $3 \mathrm{~g} / \mathrm{m}^{2} \mathrm{P}_{2} \mathrm{O}_{5}$ besides the low soil $\mathrm{P}$ content (4.60 ppm) could be related to the reaching of P supply to the optimal level or the limitation of yield potential of tef relative to high $\mathrm{P}$ supply. It has also been reported that when the supply of one nutrient is increased, the other nutrients or the genetic potential of the plants become the limiting factors [7]. In present experiment, the yield increase with the increase in $\mathrm{P}$ rate was related to the increase in total biomass, harvest index, panicle weight and seed weight/plant.

In the present experiment, the delay in days to maturity at low P supply was mainly attributed to the delay in days to flowering than the grain filling period. Indeed, limited P supply reduces leaf area duration, and limits supply of $\mathrm{P}$ and photosynthates to the grain subsequently reducing grain filling period [7]. As to the present experiment, early flowering with the supply of $\mathrm{P}$ has been reported for tomato [31] and wheat [32]. This could be because $P$ supply increases cytokinins synthesis [33] and supply of photosynthates [7] for flower formation.

As to the present experiment, the increase in $\mathrm{P}$ supply increased grain $\mathrm{P}$ in maize [19,34], amaranth [27] and sorghum [28], grain N and $\mathrm{K}$ in maize [34], total plant $\mathrm{P}$ in maize [19], soya bean [25], wheat [26], rice [20,29] and sorghum [28], and total plant $\mathrm{N}$ and $\mathrm{K}$ in sorghum [28]. The increase in nutrient accumulation with the increase in P supply could be related to improved root system development [25], and increased availability of nutrients due to increased soil $\mathrm{pH}$ [27].

As to the present experiment, the decline in $\mathrm{P}$ physiological efficiency for soybean [25], and apparent recovery and agronomic efficiency for maize [19] and soybean [25] with the increase in P supply has also been reported. This could be due to the limiting effect of other nutrients with increasing level of $\mathrm{P}[6,19]$. It has also been reported that high nutrient efficiency is generally obtained at low soil nutrient supplies or when rate of nutrient application is not too high [6].

As to the present experiment, varietal differences in grain $P$ in maize [19], total plant $P$ in maize [19] and rice [29], and P efficiency in amaranth [27] have also been reported. Moreover, the differences in apparent recovery could be related to the differences in root characteristics [7]. The present experiment suggests that excess P supply beyond $3 \mathrm{~g} / \mathrm{m}^{2}$ could result in low grain yield increase and low $\mathrm{P}$ recovery requiring soil $\mathrm{P}$ assessment prior to fertilizer application. Moreover, variety DZ-Cr-37 may be incorporated in future breeding programs for $\mathrm{P}$ efficiency in tef.

\section{Acknowledgements}

The author thanks Dilla University, Ethiopia, for financial support for the project.

\section{REFERENCES}

[1] S. Ketema, "Tef (Eragrostsis tef) Series: Promoting the Conservation and Use of Underutilized and Neglected Crops,” Institute of Plant Genetics and Crop Plant Research, Getersleben/International Plant Genetic Resources Institute, Rome, 1997.

[2] CSA (Central Statistical Authority), “Agricultural Sample Survey, 2001/02 Area and Production for Major Crops Private Peasant Holdings,” Statistical Bulletin No. 227, Addis Ababa, 2003.

[3] A. Negassa, A. Gemeda, T. Kumsa and G. Gedano, "Agroecological and Socioeconomic Circumstance of Farmers of East Wollega Zones of Oromia Region,” IAR Research Report, Addis Ababa, 1997.

[4] A. Woldeab, T. Mamo, M. Bekele and T. Alema, "Soil Fertility Management Studies on Wheat in Ethiopia. In: H. Gebre Mariam, D. G. Tanner and M. Huluka, Eds., Wheat Research in Ethiopia: A Historical Perspective, IAR/ CIMMYT, Addis Ababa, 1991, pp. 137-172.

[5] T. Mamo and I. Haque, "Phosphorus Status of Some Ethiopian Soils. II. Forms and Distribution of Inorganic Phosphorus and Their Relation to Available Phosphorus," Trop.Agric. (Trinidad), Vol. 68, No. 1, 1991, pp. 2-8.

[6] K. Mengel and E. A. Kirkby, "Principles of Plant Nutrition," 4th Edition, Panima Publishing Corporation, New Dehli, 1987.

[7] H. Marschner, "Mineral Nutrition of Higher Plants," 2nd Edition, Academic Press, San Diego, 1995.

[8] R. D. Graham, "Breeding for Nutritional Characteristics in Cereals,” In: P. B. Tinker and A. Lauchli, Eds., Advances in Plant Nutrition, Praeger Publishing, New York, Vol. 1, 1984, pp. 57-102.

[9] L. Ozturk, S. Eker, B. Torun and I. Cakmak, "Variation in Phosphorus Efficiency among 73 Bread and Durum Wheat Genotypes Grown in a Phosphorus-Deficient calcareous Soil,” Plant Soil, Vol. 269, No. 1-2, 2005, pp. 6980. http://dx.doi.org/10.1007/s11104-004-0469-z

[10] B. Sattelmacher, W. J. Horst and H. C. Becker, "Factors That Contribute to Genetic Variation for Nutrient Efficiency of Crop Plants," Journal of Plant Nutrition and Soil Science, Vol. 157, No. 3, 1994, pp. 215-224.

[11] D. Föhse, N. Claassen and A. Jungk, "Phosphorus Effi- 
ciency of Plants. I: External and Internal P Requirement and P Uptake Efficiency of Different Plant Species," Plant Soil, Vol. 110, No. 1, 1998, pp. 101-109. http://dx.doi.org/10.1007/BF02143545

[12] J. P. Lynch and K. M. Brown, “Topsoil Foraging-An Architectural Adaptation of Plants to Low Phosphorus Availability," Plant Soil, Vol. 237, No. 2, 2001, pp. 225237. http://dx.doi.org/10.1023/A:1013324727040

[13] T. S. Gahoonia and N. E. Nielsen, "Barley Genotypes with Long Root Hairs Sustain High Grain Yields in Low-P Field," Plant Soil, Vol. 262, No. 1-2, 2004, pp. 55-62.

http://dx.doi.org/10.1023/B:PLSO.0000037020.58002.ac

[14] S. J. Yun and S. M. Kaeppler, "Induction of Maize Acid Phosphatase Activities under Phosphorus Starvation," Plant Soil, Vol. 237, No. 1, 2001, pp. 109-115. http://dx.doi.org/10.1023/A:1013329430212

[15] J. Wasaki, T. Yamamura, T. Shinano and M. Osaki, "Secreted Acid Phosphatase Is Expressed in Cluster Roots of Lupin in Response to Phosphorus Deficiency," Plant Soil, Vol. 248, No. 1-2, 2003, pp. 129-136. http://dx.doi.org/10.1023/A:1022332320384

[16] J. R. Caradus and R. W. Snaydon, “Aspects of Phosphorus Nutrition of White Clover Populations. I: Inorganic Phosphorus Content of Leaf Tissue," Journal of Plant Nutrition, Vol. 10, No. 3, 1987, pp. 273-285. http://dx.doi.org/10.1080/01904168709363572

[17] T. S. Gahoonia, N. E. Nielsen and O. B. Lyshede, "Phosphorus (P) Acquisition of Cereal Cultivars in the Field at Three Levels of P Fertilization,” Plant Soil, Vol. 211, No. 2, 1999, pp. 269-281. http://dx.doi.org/10.1023/A:1004742032367

[18] L. D. Osborne and Z. Rengel, "Screening Cereals for Genotypic Variation in Efficiency of Phosphorus Uptake and Utilization," Australian Journal of Agricultural Research, Vol. 53, No. 3, 2002, pp. 295-303. http://dx.doi.org/10.1071/AR01080

[19] A. H. A. Hussein, "Phosphorus Use Efficiency by Two Varieties of Corn at Different Phosphorus Fertilizer Application Rates," Journal of Applied Sciences Research, Vol. 4, No. 2, 2009, pp. 85-93.

[20] N. K. Fageria and V. C. Baligar, "Upland Rice Genotypes Evaluation for Phosphorus Use Efficiency," Journal of Plant Nutrition, Vol. 20, No. 4-5, 1997, pp. 499-509. http://dx.doi.org/10.1080/01904169709365270

[21] J. M. Bremner, “Total Nitrogen,” In: C. A. Black, D. D. Evants, L. E. Ensminger, J. L.White, F. E. Clark and R. C. Dinaeur, Eds., Methods of Soil Analysis, American Society of Agronomy, Madison, 1965, pp. 1149-1178.

[22] AOAC, “Official Methods of Analysis," 12th Edition, Association of Official Analytical Chemists (AOAC), Washington DC, 1975.

[23] SAS, "The SAS System for Windows," V6.12, SAS, Carry, 1996.

[24] A. Deressa, W. Negassa, F. Getaneh and B. Dinsa, "Response of tef to Nitrogen and Phosphorus Fertilizers under Farmers' Conditions,” In: A. Zeleke, H. Tefera, G.
Keneni, A. Ayana, T. Tefera, S. Assefa, D. Debelo and B. Simane, Eds., Sebil: Proceedings of the 11th Conference of the Crop Science Society of Ethiopia, Addis Ababa, 2004, pp. 176-181.

[25] K. N. Devi, L. N. K. Singh, T. S. Devi, H. N. Devi, T. B. Singh, K. K. Singh and W. M. Singh, "Response of Soybean [Glycine max (L.) Merrill] to Sources and Levels of Phosphorus," Journal of Agricultural Science, Vol. 4, No. 6, 2012, pp. 44-53.

[26] A. Gunes, A. Inal, M. Alpaslan and I. Cakmak, "Genotypic Variation in Phosphorus Efficiency between Wheat Cultivars Grown under Greenhouse and Field Conditions,” Soil Science and Plant Nutrition, Vol. 52, No. 4, 2006, pp. 470-478. http://dx.doi.org/10.1111/j.1747-0765.2006.00068.x

[27] O. D. Ojo, E. A. Akinrinde and M. O. Akoroda, "Phosphorus Use Efficiency in Amaranth (Amaranthus cruentus L.)," International Journal of AgriScience, Vol. 1, No. 2, 2011, pp. 115-129.

[28] A. Akram, M. Fatima, S. Ali, G. Jilani and R. Asghar, "Growth, Yield and Nutrients Uptake of Sorghum in Response to Integrated Phosphorus and Potassium Management," Pakistan Journal of Botany, Vol. 39, No. 4, 2007, pp. 1083-1087.

[29] E. A. Akinrinde and T. Gaizer, "Differences in the Performance and Phosphorus-Use Efficiency of Some Tropical Rice (Oryza sativa L.) Varieties," Pakistan Journal of Nutrition, Vol. 5, No. 3, 2006, pp. 206-211. http://dx.doi.org/10.3923/pjn.2006.206.211

[30] T. Mamo, C. Richter and A. Hoppenstedt, "Phosphorus Response Studies on Some Varieties of Durum Wheat (Triticum durum Desf.) and tef (Eragrostis tef (Zucc) (Trotter) Grown in Sand Culture,” Journal of Agronomy and Crop Science, Vol. 176, No. 3, 1996, pp. 189-197. http://dx.doi.org/10.1111/j.1439-037X.1996.tb00463.x

[31] R. C. Menary and J. van Staden, "Effects of Phosphorus Nutrient and Cytokinins on Flowering in the Tomato (Lycopersicon esculentum Mill)," Australian Journal of Plant Physiology, Vol. 3, No. 2, 1976, pp. 201-205. http://dx.doi.org/10.1071/PP9760201

[32] M. S. Rahman and J. H. Wilson, "Effect of Phosphorus Applied as Superphosphate on Rate of Development and Spikelet Number per Ear in Different Cultivars of Wheat," Australian Journal of Agricultural Research, Vol. 28, No. 2, 1977, pp. 183-186. http://dx.doi.org/10.1071/AR9770183

[33] J. M. Horgan and P. F. Wareing, "Cytokinins and the Growth Response of Seedlings of Betula pendula Roth. and Ancer pseudoplantanus L. to Nitrogen and Phosphorus Deficiencies,” Journal of Experimental Botany, Vol. 31, No. 121, 1980, pp. 525-532. http://dx.doi.org/10.1093/jxb/31.2.525

[34] M. A. Hussaini, V. B. Ogunlela, A. A. Ramalan and A. M. Falaki, "Mineral Composition of Dry Season Maize (Zea mays L.) in Response to Varying Levels of Nitrogen, Phosphorus and Irrigation at Kadawa, Nigeria,” World Journal of Agricultural Sciences, Vol. 4, No. 6, 2008, pp. 775-780. 